\title{
113 常磐宸田多賀地区の粘土について
}

\section{1. 緒言}

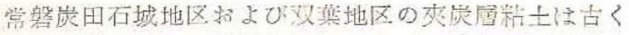
か、ら耐火粘土として開発されているが，多唯地区ては一

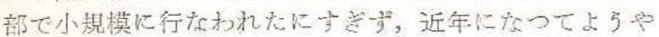

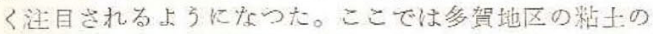

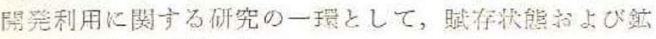
钩組成について述ベる。

\section{2. 地 質 概 説}

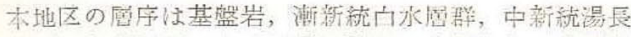

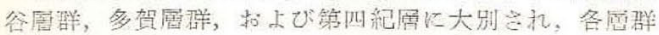

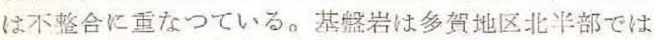
主に緑色片宕からなり, 南半部は花溯岩類からなる。南

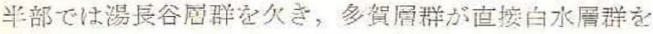

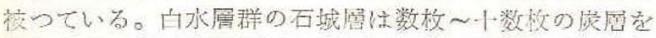

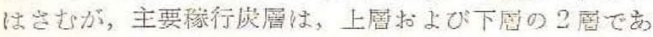
る。第三紀畨の一般走向は活!南北で，目に $10 \sim 15^{\circ}$ 倾 斜している。

\section{3. 钩床}

本地区の粘土航术住，(1) 石城居基底部の蛙目粘土,

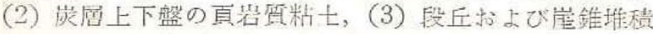
物中の啋土に大別され，その座状は次のと岕りである。

（1）蛙目粘土 基盤の不整合面はかなりの起伏学有 し，とくに多贺地区北部と胡部にはところどころに大茜

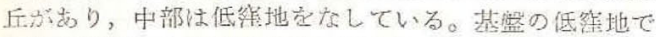

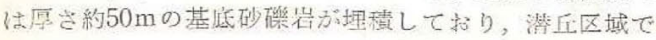

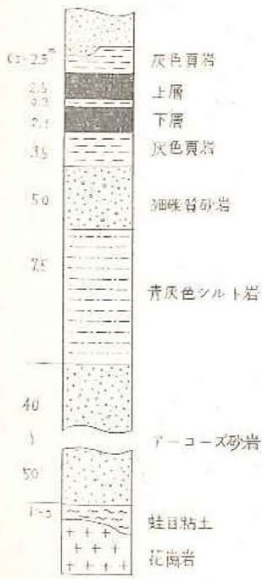

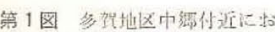
け石城展下部心抽筧 柱状桴

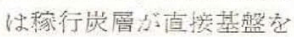
被つている。

㤬日粘土梳石城層基底 部にあり，著しく風化し た花崫岩疮被つており， 曆さ $3 \mathrm{~m}$ 以下厄, 薑続珄

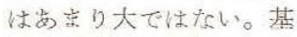
盤の形態々㤬日粘上の分 布との疄保はまだ朋らか。 ではないぶ, 現在確認さ れるものは基盤の低䆶地 にあり, 上方にアーコー ス゚砂岩に移化する。緑色

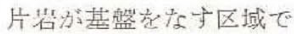
は, 基底部に片若の侍磞 を含絊色〜瞕色の粘土 か゚しばしぱ存在与るが， カネりン質粘士は誌めら れたい。

（2）炭層上下盤の頁

\begin{tabular}{|c|c|c|c|}
\hline 東北大学:工学部教投·理博 & 江 & 口 & 元 \\
\hline 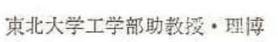 & 庄 & 司 & 力 \\
\hline 東北大学工学部助手・工搏 & ○鈴 & 木 & 舜 \\
\hline
\end{tabular}

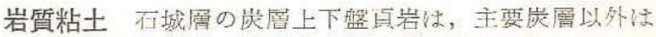

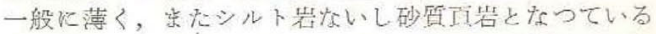
わのが多い。主要炭層の上捣招よび下嵓は大潜丘部を除

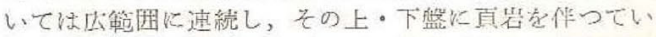

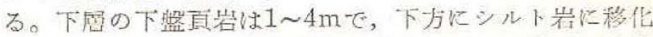

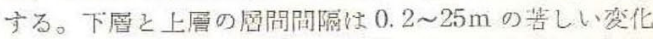

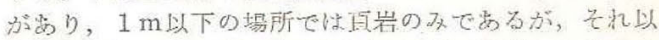

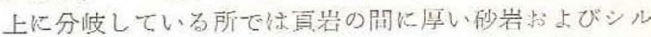

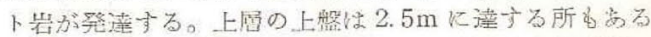

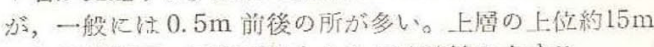

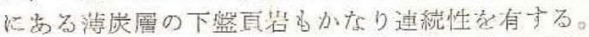

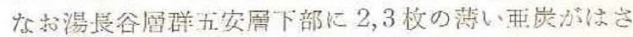
まれ，その上下盤に灰〜音灰色泥岩を俳つているが，遧 続性に泛しい。

（3）段丘および崖錐堆積物中の粘土 第三紀層分市 区城は低い丘陵地形火なし, 数段の段丘吕発㜔してい る。甚盤靣露出区域忙較的急峻な山地をなし, その麓 部に小規模な崖雓を生じている。殅雓は一部に抋いて段 丘堆筫物に速なつている。

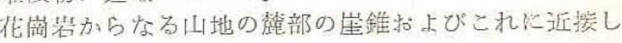
た段丘堆程物中には砂磪のマトリックスななはレンズと して蛙日状の秒質粘士がしばしば含まれている。その分 布は不規剘で，変化が多い。

\section{4. 鉱 物 組 成}

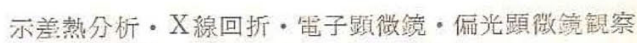
和上び化学分析の結果は次のと打りである。

（1）蛙目粘土 多基の石英と小量の辰不を含双，粘 土は20 30\%で恋る。水筑した粘土は白色で粘性強く， 多少脂感老呈する。

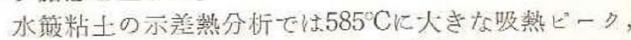
$965^{\circ} \mathrm{C}$ に大きな登熱ピークがある、X線回折ではカオり ナーイトと石英の混合物で岕ることを示す。䉓子顥微鏡て は不定形の石英粒と0.1〜 1 2 内外の六角板状ないし半自 形のカオリンイトからなつている。これらから結品度の 低いカホリナイトそ石英の湿合物と考えられる。

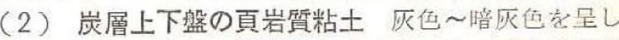

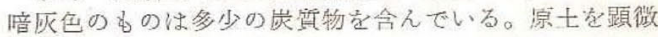
镜下でみるる，主に $20 \mu$ 以下の石英抋上び粘土からなつ ており，しぱしば50〜100 有色銃物的少量認好らる。

原土の示新熱分析では，130 150 CK小さな吸熟ピー

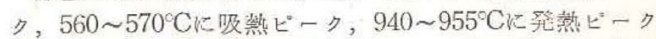
があるが，蛙目粘土恬ど著しくない。X線回折では多量 の不英とカォリナイトの混合物で山るととを示す。留子 顕微镜では微細な不英粒と六角板状ないし半自形のカオ リナイトが認められる。これらから石英と結晶应の低い カオリナイト姿主とする混合物で, 石英の量比かか心り 
